DOI

\title{
ПЕДАГОГІЧНІ (МЕТОДИЧНІ) ЗАСАДИ ВИКЛАДАННЯ КУРСУ “МЕДИЧНЕ ПРАВОЗНАВСТВО” ДЛЯ СТУДЕНТІВ МЕДИЧНОГО ФАКУЛЬТЕТУ
}

\author{
Н. М. Калинюк, І. О. Рогальський, М. В. Чорненький
}

ДВНЗ “Тернопільський державний медичний університет імені I. Я. Горбачевського

мОЗ України”

\section{PEDAGOGICAL (METHODICAL) BASE ON TEACHING THE COURSE “MEDICAL LEGISLATION” FOR STUDENTS OF MEDICAL FACULTY}

\author{
N. M. Kalyniuk, I. O. Rohalskyi, M. V. Chornenkyi \\ SHEI “Ternopil State Medical University by I. Ya. Horbachevsky of MPH of Ukraine”
}

\begin{abstract}
У статті здійснено аналіз правового забезпечення підвищення рівня правової освіти для студентів медичних факультетів вищих медичних закладів. Виокремлено основні педагогічні засади викладання курсу “Медичне правознавство”, завданням яких є формування правової компетентності студентів медичного факультету. 3'ясовано сутність достатнього обсягу об’єктивних можливостей освітнього процесу і внутрішньої мотиваційної основи студентів-медиків як педагогічних засад викладання курсу “Медичне правознавство” для студентів медичних факультетів вищих навчальних закладів. Визначено доцільність застосування педагогічних засад при викладанні курсу “Медичне правознавство” для студентів-медиків.
\end{abstract}

This article analyses the legal base on increasing the level of law education for students of medical faculties of medical universities. Fundamental pedagogical issues for teaching the course "Medical Legislation" are justified. It was found out the sufficiency of objective abilities of educational process and internal motivation of medical students which are the pedagogical bases of the training the course. The article assesses the advisability of using pedagogical principles while teaching "Medical Legislation".

Вступ. Якісний процес право- і державотворення в Україні є можливим завдяки підготовці молодого покоління до належної життєдіяльності у правовому громадянському суспільстві. Одним 3 основних елементів навчального процесу у вищій школі $є$ правова освіта, пріоритетним завданням якої $€$ виховання молоді на засадах поваги до права, прав і свобод людини і громадянина, підвищення правової культури, правової свідомості, іï ціннісних орієнтирів.

Система вищої освіти у медичних навчальних закладах спрямована на становлення високого рівня правової поінформованості студента-медика. I це з тих причин, що векторна модель компетентнісно зорієнтованого курсу “Медичне правознавство” включає в себе комплекс заходів виховного, навчального та інформаційного характеру, основним завданням яких є створення належних умов для отримання студентами медичного факультету достатнього обсягу правових знань і навичок, необхідних для їх застосування у сфері охорони здоров’я.

() Н. М. Калинюк, І. О. Рогальський, М. В. Чорненький
Доцільність засвоєння студентами медичного факультету курсу “Медичне право” варто визначити за компетентнісним підходом, що за своєю сутністю спрямовує навчальну діяльність студентів на попередньо визначений результат. Це надасть можливість визначити надалі ефективність навчання, що допомагає оцінювати результати діяльності суб'єктами навчання за ступенем наближення результатів до заданих цілей [1].

Становлення і розвиток навчального курсу “Медичне правознавство” бере свій початок в умовах суверенної Української держави. Формування громадянського суспільства, демократизація публічноправових процесів та інтеграція до світової та європейської спільноти зумовили необхідність зародження нової галузі знань. Зазвичай відносини, що виникають у сфері охорони здоров'я, грунтуються на принципах моралі та звичаєвих правилах. Разом 3 тим, $з$ підвищенням вимог до якості надання медичної допомоги та медичних послуг беззаперечною $є$ доцільність правового регулювання цих відносин. Медичне право як галузь права вивчає проблематику розробки і реалізації правових норм, 
що закріплюють особисті, соціальні, політичні, трудові, економічні гарантії прав людини у сфері охорони здоров’я. Тому засвоєння студентами медичного факультету основних аспектів правового регулювання у сфері охорони здоров'я слід вважати одним з пріоритетних завдань медичного права як напряму правової освіти і державної політики в цілому.

Основна частина. Динамічний розвиток медицини зумовлює важливість вивчення курсу “Медичне правознавство” студентами медичного факультету з метою формування громадської свідомості щодо прав та обов’язків учасників медичних правовідносин, підвищення рівня розуміння необхідності знати свої права та дотримуватися встановлених правовими нормами обов'язків.

У різних аспектах навчально-методичні рекомендації до курсу “Медичне правознавство” досліджували у своїх працях такі вчені, як А. Бабанін, М. Білінська, 3. Гладун, В. Краєвський, В. Ольховський, I. Сенюта, С. Стеценко, X. Терешко та ін. Разом 3 тим, основні педагогічні засади викладання курсу “Медичне правознавство”, що впливають на формування правової компетентності майбутніх медиків, не були предметом окремих досліджень i потребують наступного вивчення. Метою статті є визначення педагогічних (методичних) засад викладання курсу “Медичне право” для студентів медичного факультету.

До основних педагогічних засад викладання курсу “Медичне правознавство” у процесі формування правової компетентності студентів медичного факультету необхідно віднести такі умови, як достатній обсяг об’єктивних можливостей освітнього процесу і внутрішню мотиваційну основу студентів-медиків.

Достатній обсяг забезпечення можливостей освітнього процесу щодо викладання курсу “Медичне правознавство” на медичному факультеті у вищій школі реалізується на основі програм, рекомендацій і методичних вказівок, що затверджуються відповідними міністерствами та відомствами.

Обсяг та зміст обов’язкового курсу “Медичне правознавство” зумовлені потребами суспільства у вихованні правосвідомого конкурентоспроможного фахівця-медика, високими стандартами якості вищої освіти при наданні освітньо-кваліфікаційного рівня особі. Викладання курсу “Медичне правознавство” для студентів медичного факультету є абсолютно закономірним проявом до тенденції правового забезпечення захисту прав медичних працівників та пацієнтів. Ця потреба зумовлена розвитком приватної медичної практики, впро- вадженням добровільного медичного страхування та розробкою нормативно-правової бази щодо загальнообов'язкового державного соціального медичного страхування, використання новітніх технологій та досягнень медичної науки (трансплантології, репродуктивних технологій, клонування, телемедицини та ін.).

При визначенні основних положень освітньої програми курсу “Медичне правознавство”, насамперед, зроблено акцент на відносинах, що регулюються медичним правом, які виникають у процесі реалізації права громадян на охорону здоров’я. Норми медичного права регулюють суспільні відносини, пов’язані з організацією, оплатою та наданням медичної допомоги, медичної послуги, забезпеченням якісного медичного обслуговування.

Достатній обсяг об’ єктивних можливостей освітнього процесу при викладанні курсу “Медичне правознавство” на медичному факультеті забезпечує й самоосвіта. Методичні рекомендації з питань самоосвіти у галузі правової самоосвіти розробляються Міністерством освіти і науки України, Міністерством юстиції України, Інститутом держави і права імені В. М. Корецького НАН України, Академією правових наук України та періодично публікуються у виданнях педагогічного, юридичного, культурно-освітнього спрямування [2].

Основу правового забезпечення викладання курсу “Медичне правознавство” для студентів медичного факультету у вищих навчальних закладах, що підпорядковані МО3 України, становить затверджена Державною установою “Центральний методичний кабінет з вищої медичної освіти МОЗ України” типова навчальна програма $з$ дисципліни “Медичне правознавство” галузі знань 1201 “Медицина” для спеціальностей 12010001 “Лікувальна справа”, 12010002 “Педіатрія”, 12010003 “Медикопрофілактична справа”, 12010004 “Медична психологія” від 24.02.2015 р. У ній визначено конкретні цілі та завдання, що ставляться перед студентами медичного факультету при засвоєнні знань та вмінь з курсу “Медичне правознавство”. До них віднесено: історію становлення юридичної регламентації медичної діяльності в Україні; конституційне регулювання прав людини у сфері охорони здоров’я в Україні; загальне і спеціальне законодавство у сфері охорони здоров'я; види юридичної відповідальності за професійні правопорушення в окресленій царині; права й обов’ язки суб’єктів медичних правовідносин (пацієнтів, медичних працівників, законних представників пацієнта); дефекти надання медичної допомоги; ятрогенна патологія та її медико-правове значен- 
ня; механізми контролю якості медичної допомоги; правове регулювання сімейної медицини в Україні; правове регулювання надання психіатричної допомоги; юридичні аспекти профілактики і лікування інфекційних хвороб; законодавче забезпечення донорства (крові, тканин, репродуктивних клітин); правове регулювання паліативної допомоги; регулювання експертної діяльності за законодавством України; особливості правового забезпечення населення лікарськими засобами.

Проведений аналіз обсягу об’єктивних можливостей освітнього процесу при викладанні курсу “Медичне правознавство” для студентів медичного факультету дає підстави для висновку про його достатній рівень забезпечення. Разом з тим, педагогічні засади викладання тієї чи іншої дисципліни не можливо розглядати індивідуально, оскільки вони за своєю сутністю є взаємодоповнюючими. 3 цих причин забезпечення високого рівня ефективності реалізації об’єктивних можливостей освітнього процесу щодо викладання курсу “Медичне правознавство” для студентів медичного факультету вбачаємо у тісному взаємозв'язку з виробленням внутрішньої мотиваційної основи у студентів-медиків. Враховуючи зазначене, вважаємо, що формування у студентів медичного факультету мотиваційної основи для засвоєння знань з курсу “Медичне правознавство” є можливим при врахуванні таких критеріїв, як: 1) розроблення змісту дисципліни, зважаючи на напрям підготовки; 2) врахування основних аспектів провадження медичної діяльності; 3) аналіз юридичної практики з питань вирішення справ, пов’язаних з медичними правовідносинами; 4) визначення низки проблемних правореалізаційних моментів, з якими зустрічаються медичні працівники при наданні медичної допомоги.

Використання означених критеріїв при викладанні курсу “Медичне правознавство” для студентів медичного факультету надасть можливість зосередити увагу студентів-медиків під час занять на обраній проблематиці, наповнити курс сутнісним

\section{Список літератури}

1. Будас А. Методичні умови ефективності навчання правознавства студентів економічних спеціальностей / А. Будас // Збірник наукових праць Уманського державного педагогічного університету. - 2014. Ч. 2. - С. 59-65. - Режим доступу : http://nbuv.gov.ua/ j-pdf/znpudpu_2014_2_10.pdf_.

2. Про Національну програму правової освіти населення : Указ Президента України від 18.10.2001 р. № 992/2001 // Офіційний вісник України. - 2001. - змістом завдяки використанню прикладів з правозастосовної практики та життєвих ситуацій; виробити пізнавальну потребу у студента-медика в ознайомленні з додатковими джерелами інформації, інформаційно-пошуковими системами, зокрема матеріалами судової практики у сфері охорони здоров'я; створить умови для мотивованої участі студентів-медиків у студенських наукових гуртках з секції медичного права, розробленні правових проектів та заходів, зокрема участь у діяльності медико-юридичних клінік з метою формування правової готовності до майбутньої практичної роботи у сфері охорони здоров’я.

Висновки. Медична діяльність, як і будь-які інші види діяльності, потребує правового регулювання. Засвоєння основних положень медичного права, що регулює медичні правовідносини, при викладанні курсу “Медичне правознавство” для студентів медичного факультету є важливим для формування успішної особистості, конкурентоспроможності майбутнього фахівця-медика.

Медичне правознавство як окрема самостійна навчальна дисципліна зумовлена сутністю стратегічного реформування системи охорони здоров'я на 2015-2025 рр. [3]. Її вивчення забезпечить компетентнісно зорієнтованого майбутнього спеціалістамедика, конкурентоспроможного фахівця у контексті засвоєння знань, умінь і навичок щодо загальнообов’язкового державного медичного страхування, лікарського самоврядування, ліцензування медичної практики, що забезпечить підвищення якості медичного обслуговування населення.

Забезпечення високого рівня засвоєння правових знань та вмінь у сфері охорони здоров'я студентами медичного факультету є можливим завдяки застосуванню основних педагогічних засад при викладанні курсу “Медичне правознавство”. До основних педагогічних (методичних) умов при викладанні курсу “Медичне правознавство” відносимо: забезпечення достатнього обсягу об’єктивних можливостей освітнього процесу та внутрішню мотиваційну основу студента-медика.

№ 42. - Ст. 48 [Електронний ресурс]. - Режим доступу : http://zakon4.rada.gov.ua/laws/show/992/2001.

3. Концепція нової національної системи охорони здоров’я України : Проект розпорядження КМУ [Електронний ресурс]. - Режим доступу : http://www.moz.gov. ua/docfiles/dod_Pro_20140618_0.pdf.

Отримано 02.06.15 